\title{
THE ENDOGENEITY PROBLEM AND FDI IN TRANSITION: EVIDENCE FROM THE PRIVATIZED GLASS SECTOR IN THE CZECH REPUBLIC
}

\author{
Elisa Galeotti, Eva Ryšavá*
}

\begin{abstract}
:
This paper analyses the crucial factors determining the foreign direct investment (FDI) going to the privatized glass sector in the Czech Republic. In our research we felt that there was a scant evidence in Central and Eastern Europe of the determinants of foreign direct investments (FDI) at the micro level and we were aware of the endogeneity issue of FDI. The aim of this paper is to fill these gaps. The choice of the glass sector allows for an analysis of a firm's micro characteristics that attract foreign direct investors in an industrial sector, while reducing the impact of macroeconomic factors in their choice. Our econometrical analysis, using original panel data from 1990 to 2006, gives strong evidence that foreign direct investors in the glass sector in the Czech Republic have chosen larger and more profitable firms that were intensively restructured and privatized at the beginning of the transition. Our results support the relevance of the endogeneity issue in the choice of foreign direct investors in transition countries.
\end{abstract}

Keywords: foreign investors, performance, panel data, endogeneity, Czech Republic, glass industry.

JEL classification: L61, F21, F23, G3, C23, C25

\section{Introduction}

Much of the existing research on privatization in Central and Eastern Europe has analysed the impact of foreign direct investors on the performance and restructuring of the formerly state-owned enterprises, based on agency theory arguments and on the assumption that ownership was exogenous. Foreign ownership has contributed to the improvement of productivity, performance and restructuring in domestic firms by creating new incentives and transferring capital, technology and managerial know-how (Djankov and Murrell, 2000; Dyck, 1997).

The Ownership, Location and Internalization Model (OLI) and other theories explain the foreign market entry mode. ${ }^{1}$ The OLI theory shows the reasons that push

* Charles University, Institute of Economic Studies, Prague (elisagaleotti@seznam.cz; rysavaeva@volny.cz). Authors would like to thank Emiliya Lazarova from the Queen's University Belfast and Serena Pattaro from the Nuffield College Oxford for their valuable advice, Prof. Evžen Kočenda, Prof. Štepán Jurajda and Juraj Stančík from the Cerge-EI Prague for useful comments, Prof. Michal Mejstrík for his support, and participants of the ELBF seminar (October 2007) for discussion. GA UK Grant (2157/2007) is acknowledged as a source of financial support.

1 For a summary of the theories and empirical studies about foreign market entry mode, see Zhao and Decker, 2004. 
foreign investors to enter a country and to invest in some companies - a choice that is not casual but depends on some specific advantages that foreign investors perceive. Following Demsetz (1983), Demsetz and Lehn (1985) and Demsetz and Villalonga (2001), we argue that ownership should not be treated as an exogenous variable and that foreign investors have chosen privatized firms with specific characteristics.

The purpose of this article is to investigate whether the choice of foreign investors to acquire firms in the glass sector in the Czech Republic is motivated by the firm's characteristics and which of these firms' characteristics should be considered relevant.

In this paper, using a data set for 42 privatized firms in the glass sector (1990-2006), we show that foreign investors in the glass sector had chosen firms that were larger, that were potentially more profitable, that were restructured more at the beginning of the transition and that were privatized earlier than others.

The paper is organized as follows. The first section provides an overview of the privatization process in the glass sector in the Czech Republic. Next, we present a theory review that discusses the determinants of FDI in the transition countries. In subsequent sections we present methodology and econometric results for the determinants of FDI in the privatized glass sector. Last section contains our conclusions.

\section{The Privatization of the Glass Sector in the Czech Republic}

Before Soviet occupation, Bohemian glass, established in the 17th century, experienced commercial success as well as difficult times usually as a consequence of wars and adverse political or economic conditions. By 1936, 40\% of the world's glass was made in Czechoslovakia (Crystalex Branch Corporation, 1985). However, during Soviet occupation, glass factories were nationalized and the emphasis was placed on heavy industry. The production of industrial and laboratory glass, thermometers, glass fibres, glass piping, television screens and optical lenses was enlarged at the expense of household glass production.

Since 1989, the glass industry has gradually started the privatization process, and the big state glass giants, the national corporations and the sectoral corporations, such as Sklo Union and Crystalex, were gradually separated in smaller entities and privatized in different ways.

The participation of foreign investors in the privatization process in the Czech Republic was limited at the beginning of the transition with respect to the governmental objectives and the attitude of policymakers. Some companies were privatized through the voucher programme conceived as a fair method that could allow a large number of domestic adult citizens to participate in the process despite strong capital illiquidity. In some cases, with the restitution, preference was given to the owners of the glassworks, as in case of the Beranek family or the Blažek family. In other cases of privatization, the company was given to the management, as was the case of the Moser company. The government changed its behaviour towards foreign investors successively, especially after the economic and financial crisis in 1997. In April 1998, the Czech government approved a national investment incentive package and offered incentives to manufacturing investors who invested at least 10 million dollars and were able to fulfil the 
eligibility criteria. The residual privatization of banks, manufacturing and distribution firms had been implemented primarily for finding strategic foreign partners.

Table 1

The Privatization of the Glass Industry in the Czech Republic by Sector

\begin{tabular}{|l|c|c|c|c|c|c|c|}
\hline $\begin{array}{l}\text { Segment within } \\
\text { the glass sector }\end{array}$ & $\begin{array}{c}\text { Flat and } \\
\text { architec- } \\
\text { tural glass }\end{array}$ & $\begin{array}{c}\text { Container } \\
\text { glass }\end{array}$ & $\begin{array}{c}\text { Glass } \\
\text { fibres and } \\
\text { related } \\
\text { products } \\
\text { privatization } \\
\text { method }\end{array}$ & $\begin{array}{c}\text { Other } \\
\text { kind of } \\
\text { glass } \\
\text { technical } \\
\text { and } \\
\text { laboratory } \\
\text { glass) }\end{array}$ & $\begin{array}{c}\text { Utility } \\
\text { and } \\
\text { lighting } \\
\text { glass }\end{array}$ & $\begin{array}{c}\text { Glass } \\
\text { machinery } \\
\text { and } \\
\text { service for } \\
\text { glass and } \\
\text { industry }\end{array}$ & $\begin{array}{c}\text { Total } \\
\text { number of } \\
\text { companies }\end{array}$ \\
\hline $\begin{array}{l}\text { Voucher } \\
\text { privatization }\end{array}$ & & 1 & 4 & 5 & & 10 \\
\hline $\begin{array}{l}\text { Direct sale to } \\
\text { domestic } \\
\text { companies }\end{array}$ & 1 & 1 & 3 & 4 & & 9 \\
\hline $\begin{array}{l}\text { Direct sale to } \\
\text { domestic } \\
\text { individuals }\end{array}$ & & & & 1 & 9 & 1 & 11 \\
\hline $\begin{array}{l}\text { Joint-venture } \\
\text { with foreign } \\
\text { investors }\end{array}$ & 1 & 3 & & & & & 4 \\
\hline Public tender & & & & & & & \\
\hline $\begin{array}{l}\text { Restitution } \\
\text { claim }\end{array}$ & & & & 9 & 25 & 1 & 42 \\
\hline $\begin{array}{l}\text { Restitution with } \\
\text { payment }\end{array}$ & & & & & & \\
\hline Total companies & 1 & 4 & 2 & & & \\
\hline
\end{tabular}

Source: Companies' annual reports.

Table 1 demonstrates that foreign investors entered Czech glass companies through privatization in only two glass production segments, "Flat and Architectural Glass" and in "Container Glass". These glass segments use a machine-made technology to produce glass and automatization that can have a very big impact on economic performance. Foreign investors had chosen glassworks that use a more profitable technology. During privatization foreign investors had not acquired glassworks that produce hand-made glass. The "Utility and Lighting Glass" sector instead has the lowest possibility of automatization (especially hand-made glass) and increase of labour productivity: the glassworks in this sector were privatized mainly in the way of direct sale to individuals, through voucher privatization and by restitution to domestic owners. Other types of glass that are mostly machine-made are glass fibres and technical and laboratory glass. Since 1991, there have not been available data for revenues for sales for each glass segment separately, but only for some groups of glass segments, as is shown in Figures 1 and 2 below. 
Figure 1

Revenues from Sales of Own Products and Services in the Glass Sector by Subsector (in $000 \mathrm{CZK}$ )

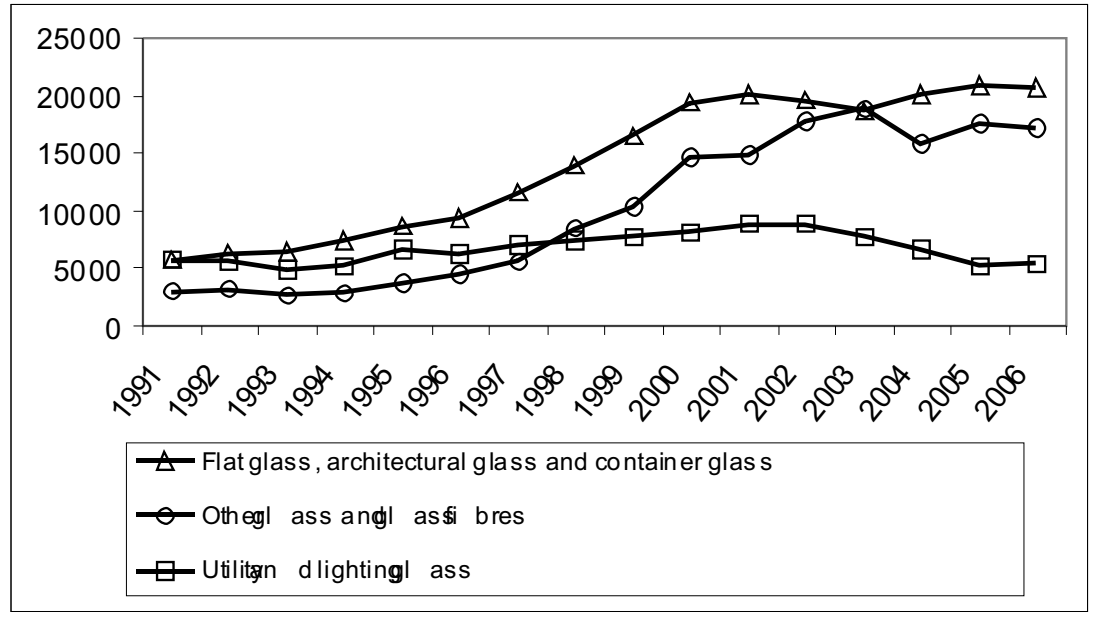

Source: The Association of the Glass and Ceramic Industry of the Czech Republic, 2001 and 2007.

Figure 2

Revenues from Sales of Own Products and Services in the Glass Sector by Subsector (in $000 \mathrm{CZK}$ )

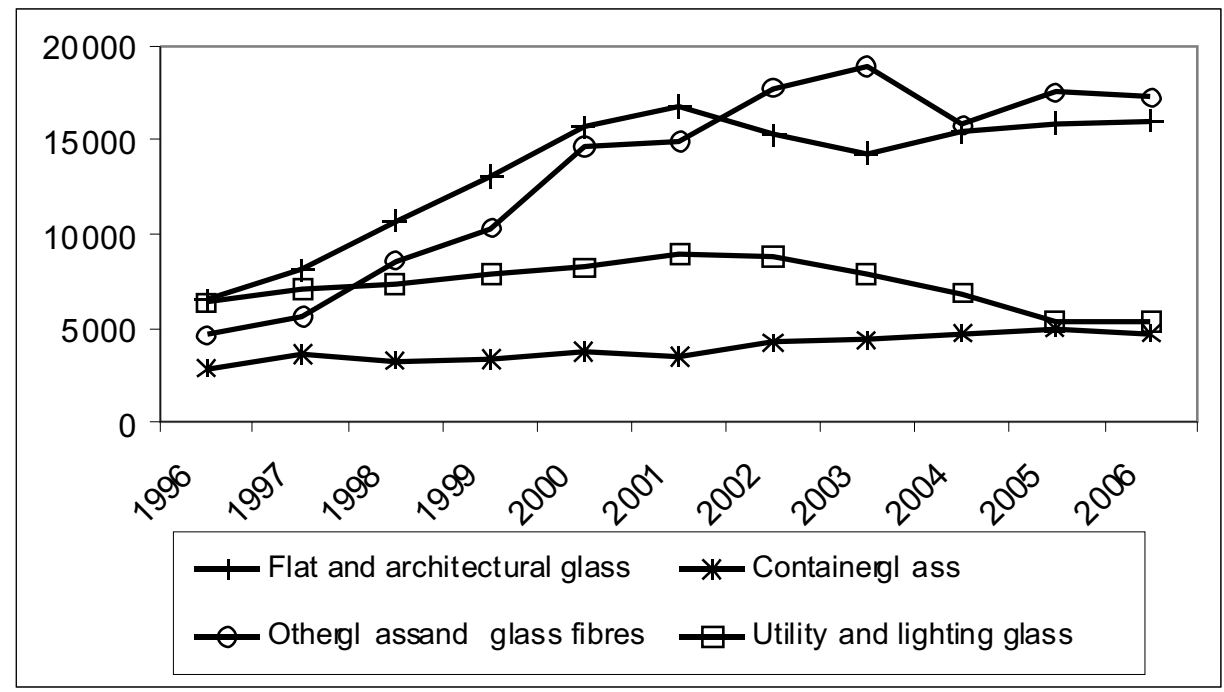

Source: The Association of the Glass and Ceramic Industry of the Czech Republic, 2001 and 2007. 
Figure 1 shows that the segment where foreign investors entered the privatization process has experienced a rapid increase in revenues from sales since 1991 and the difference of revenues compared to other segments has grown substantially. The growth in revenues in the "Other Glass and Glass Fibres" can be also partly explained by the arrival of foreign investors into this sector after the privatization. Since glassworks were privatized at different times, and foreign owners could acquire some of these firms after their privatization by buying them from a domestic owner, we consider the arrival of foreign investor during the privatization process and after it.

\section{The Investment Choices of Foreign Direct Investors in the Privatization in Transition Countries}

Most of the empirical evidence about privatization has analysed the effects of FDI on the performance of privatized firms in the transition countries (Frydman et al., 1999; Barrell and Holland, 2000; Djankov and Hoekman, 2000; Kočenda, 2003; Konings, 2001; Megginson and Netter, 2001; Lízal and Švejnar, 2002; Srholec, 2003; Weiss and Nikitin, 2004). These studies are based on the assumption that ownership is exogeneous and that ownership change will create new incentives or new control structures of the domestic managers that will force them to engage in restructuring, leading to an improvement in the firms' performance (Boycko et al., 1995).

The OLI approach (Dunning, 1980, 1998 and 2000) explains the decision of foreign investors to enter a country and to invest in some companies with three sets of advantages perceived by the investors: ownership advantages (specific to the nature and to the nationality of the owner), internalization advantages (arising from transferring ownership across national boundaries within the own organization) and location advantages (different locations have different resources, institutions and regulations affecting the revenues and the costs of production). When they decide to invest in a foreign country, investors analyse factors that are sector and firm specific and factors that are country specific.

According to Demsetz and Lehn (1985), the ownership structure is not predetermined, but it is the result of the characteristics of firms such as: firm size, capital intensity, investment rate, R\&D intensity, financial performance, and environment characteristics (Demsetz and Lehn, 1985; Kole, 1996; Loderer and Martin, 1997; Cho, 1998; Himmelberg et al., 1999).

The OLI approach and the theory from Demsetz (1983), Demsetz and Lehn (1985) and Demsetz and Villalonga (2001) suggest that most of the empirical studies about FDI in the privatization are biased, as shown by Marcincin and van Wijnbergen (1997) and Djankov and Murrell (2002). Different authors have tried to analyse the endogeneity issue to test the robustness of their results, but most of the research samples include firms privatized with only one method. Marcincin and van Wijnbergen (1997) as well as Gupta et al. (2000) show that all these studies have been biased on the weak assumption that privatization methods were applied on a randomly selected sample of enterprises. Gupta et al. (2000) analyse theoretically and empirically how competing government objectives give rise to different privatization strategies. Both Marcincin and van Wijnbergen (1997) as well as Gupta et al. (2000) test the endogeneity issue on a sample of large Czech enterprises privatized with voucher privatization and conclude that the comparison between 
companies privatized with different privatization methods do suffer from selection bias and that the privatization of a firm is not random (Marcincin and van Wijnbergen, 1997; Gupta et al., 2000), while Djankov and Murrell (2002) point out that $47 \%$ of the studies surveyed in their paper do not control endogeneity or selection problems.

In order to understand the role of FDIs in the transition countries and for privatized firms, it is important to solve the endogeneity issue. The empirical literature does not fully answer the question whether foreign investors improve a firm's economic performance or if they choose to invest in firms with a higher potential of success, if the superior performance of foreign owned firms depends on the ownership and corporate governance of the foreign investor after his arrival or if it depends on the better starting conditions of the firm. Among the few studies about the performance of privatized firms that address the endogeneity issue, Hanousek et al. (2007) show that ownership should be treated as endogenous and analyse this problem econometrically.

There are many empirical studies that analyse the determinants of FDI at the country level and the competitive advantage of the Czech Republic (Zamrazilová, 2007; Kadeřábková, 2007; Blonigen, 2005; Benáček, 2000; Benáček and Zemplinerová, 1997). Few studies have focused on the role of micro factors, a firm's characteristics that attract FDI within a sector during the privatization process.

The few empirical studies that have analysed the role of specific firm's characteristics that attract foreign direct investors in the transition countries are the following.

Anderson et al. (2001) analysing data on the 988 enterprises included in the first wave of voucher privatization in Czech Republic confirm the hypothesis that foreign investors prefer larger, safer and more profitable companies in which they can exert unchallenged influence on corporate governance. In the first wave of mass privatization, out of 998 companies, foreign investors hold equity in 41 enterprises, only $1.6 \%$ of all privatized shares. In these 41 firms the mean percentage of shares held by foreign investors was $39.2 \%$. Profitability (measured as return on equity or as revenue per employee) appears to be significantly higher in firms with a foreign investor (Anderson et al., 2001, p.162).

Also Djankov and Hoekman (2000) find that in the Czech Republic, foreign investors tend to prefer large and more profitable companies: they analyse data for the period 1992-1996 of a sample of 513 firms quoted on the Prague Stock Exchange, where $34 \%$ of the sample had a foreign link (a joint-venture or a FDI). Firms with foreign links have higher levels of initial labour productivity, measured as sales per worker in 1991, higher initial performance and size.

Tóth and Zemčík (2006) explore the motives of foreigners behind their investment in the Czech Republic, using a sample of firms from 1997 to 2002, and find that foreign investors prefer firms with a greater ownership concentration in industries with higher level of risk, in countries with lower labour costs and corporate income taxes; among specific firms' characteristics, they find that increases in the variability of the industry's profit, ownership concentration, size and industry share imply an increment in foreign ownership.

Bishop, Filatotchev and Mickiewicz (2002) analysing 162 large Hungarian firms during the period of 1994-1999 explore the determinants of equity shares held by foreign investors and by Hungarian corporations. They find evidence of a post-privatization evolution towards more homogeneous equity structures, supporting the theory from Demsetz (1983), Demsetz and Lehn (1985) and Demsetz and Villalonga 
(2001). Moreover, they find that foreign investors are attracted to the companies characterised by previous positive results in terms of performance.

\subsection{The Firm-Level Determinants}

The main firm's characteristics that attract foreign direct investors, according to the previous empirical evidence, in transition and Western countries, are the following.

\section{Performance}

Performance has been measured in the empirical studies in different ways and most of the studies conclude that foreign investors prefer to invest in profitable firms (Anderson et al., 2001; Dahlquist and Robertsson, 2001; Bishop, Filatotchev and Mickiewicz, 2002) or firms with higher productivity or factor productivity (Raff and Ryan, 2006; Arnold and Javorcik, 2005).

\section{Firm Size}

Foreign investors prefer to invest in larger firms, with higher total assets (Anderson et al., 2001; Tóth and Zemčík, 2006; Bishop, Filatotchev and Mickiewicz, 2002) and with higher market capitalization (Dahlquist and Robertsson, 2001). Anderson et al. (2001) find a positive but not significant coefficient when the firm's size is measured as the number of employees.

Larger firms can attract foreign investors because of informational asymmetries: there is more information available abroad for larger firms and the transparency in turn stimulates foreign investment (Dahlquist and Robertsson, 2001; Bishop, Filatotchev and Mickiewicz, 2002). However, foreign investors may prefer larger firms for other reasons such as the advantages associated with economies of scale and scope (Kang and Stulz, 1997).

\section{Financial State}

The evidence about the role of the financial state of the firm is weak: Anderson et al. (2001) and Tóth and Zemčík (2006) find no significant differences between firms with foreign investors and firms without them in respect to financial indices such as the debt ratio, the current-ratio and the solvency rate (cash-flow to registered capital). Dahlquist and Robertsson (2001) find a positive relationship between the current ratio and the likelihood of foreign ownership, a negative relationship between the debt-equity ratio and the presence of foreign investors.

\section{Privatization}

State-owned enterprises are less efficient than private enterprises because of lack of incentives and different interests that managers and owners have (Boardman and Vining, 1989; Hashi, 1998; Megginson and Netter, 2001). Privatization improves a firm's performance because new owners help restructuring the firm and provide new resources as capital, knowledge and technology, especially from foreign majority 
owners (Frydman et al., 1999; Claessens and Djankov, 1999), while privatization to insiders with limited foreign investors can hinder the restructuring of companies, as the Bulgarian case shows (de Arriba Bueno, 2007). Privatization can be a signal of restructuring and of economic development for foreign direct investors that can therefore prefer privatized firms to state-owned enterprises.

The endogeneity problem is discussed in most of the early empirical studies on the impact of different privatization methods (Megginson and Netter, 2001) but is covered in recent studies as well (Hanousek et al., 2007; Hanousek et al., 2004). We will not take into account the role of different methods of privatization in this paper, because this variable would be correlated with our dependent variable that shows the presence of a foreign investor.

\section{Competition}

According to the OLI theory, foreign investors are motivated to enter foreign markets if they have some firm-specific advantages that enable them to outperform local or present firms (Dunning, 1981). Since there are costs of investing in a foreign country, and especially in a transition country, the expected profits from the investment should overcome these costs. As far as the entry of a foreign firm in the market is concerned, we expect that a higher market power of the foreign investor in a given industrial sector of a country offers to the investor a monopoly rent over the domestic firms. Therefore, a positive relationship between firm's market power and foreign direct investors' arrival is expected.

On the basis of the existing theory and empirical research, as discussed above, we derive the following hypotheses:

\section{Hypothesis 1: Foreign investors will be focused on companies with higher initial performance.}

Hypothesis 2: Foreign investors will be focused on larger domestic companies.

\section{Data and Methodology}

The data used in this analysis come from different sources: the companies' annual reports available to the public in business registers, the Magnus Database, the Aspect Reports, the National Property Fund and data from the Ministry of Industry of the Czech Republic. This analysis is focused on the firms in the Czech Republic in the sector 26100, according to the Industrial Classification of Economic Activities (CZ-NACE code), i.e. firms engaged in the manufacturing of glass and glass products. The panel includes only firms that existed before 1989, that were privatized and for which financial data are available: this lead to an unbalanced panel of 42 firms with data from 1990 to 2006 and with 439 observations. The decision to focus on firms existing in the central planning is done in order to analyse their destiny after the transition, in particular the probability of the arrival of a foreign investor during the privatization process or later.

To eliminate the effect of inflation, we adjust variables measured in Czech korunas to inflation using price indices of the glass sector (sector 26100) provided by the Czech Statistical Office. 
The data available for the years 1990 and 1991 are provided by the Ministry of Industry of the Czech Republic. These data may not represent the true financial status of these firms, because of the distortions of the accounting system in these years. However, these data were available to potential foreign investors at the beginning of the transition. Since the aim of this paper is to analyse which characteristics of the firms attracted foreign investors, according to the available information, we believe that these data can provide useful insights about the determinants of early FDI. The availability of these data could also partly explain why the quickest foreign direct investors preferred larger firms with higher total sales that were more visible. When foreign direct investors were not interested in some large glassworks, these glassworks were later separated in smaller firms and privatized in different ways to domestic firms or to later foreign investors.

In 1990 and 1991, most of the glass firms were still glass giants, and only after 1990 most of these giants were broken up and some parts of the glassworks were sold separately, given as restitution claims to different owners or privatized with different methods. Therefore, the data provided by the Ministry of Industry do not catch entirely all the units that participated to the privatization process. The data about firm's characteristics in 1993 and 1994, derived from the companies' annual reports and from the Magnus database, are also relevant and more complete since the majority of firms in these years were already divided into separate units and ready to be privatized.

\section{Explanatory Variables}

We use the following variables: we consider initial performance measures as the level of productivity and the amount of gross profit margin. We also consider initial financial measures as the values of debt ratio and current ratio. Then we include the number of years from privatization, the percentage of machine-made production and initial firm size, measured as the natural logarithm of the number of employees. We measure the initial firm's characteristics with the data from 1990 and 1991. We use also data from 1993 and 1994 to measure firm's initial conditions and to check the robustness of our results.

\section{Performance}

We use the level of productivity (measured as total sales per employee) and the value of gross profit margin (net operating result before taxes over total sales). We expect a positive effect of initial performance variables on the likelihood of arrival of foreign investors in our sample because privatization can be a signal of restructuring and of economic development for foreign investors that can therefore prefer privatized firms to state-owned enterprises.

\section{Firm Size}

We use the natural logarithm of the number of employees as the firm's size.

We expect a positive effect of firm's size on the likelihood of arrival of foreign investors because larger firms are more visible abroad and because of the advantages associated with economies of scale and scope (Kang and Stulz, 1997). 


\section{Financial State}

We use the debt ratio and the current ratio in 1993 and 1994. While the previous evidence has not found a strong significant relationship between the initial financial state and the probability of FDI, we expect that foreign investors have preferred Czech firms with a sound financial state and therefore we expect a negative sign for the coefficient of debt ratio and a positive sign for the coefficient of current ratio.

\section{Privatization}

We measure the impact of privatization with the number of years from the privatization (for state-owned enterprises this variable, with a negative sign, indicates the number of years before the privatization).

We expect a positive effect of the time from the privatization on the likelihood of arrival of foreign investors.

\section{Type of Production}

In the glass sector, there exist different subsectors that differentiate firms. Glassworks manufacture different products with various techniques. The main difference concerns firms with an automatic production and glassworks with a hand-made production. We include a control variable that indicates the percentage of automatic or machine-made production.

Foreign investors might be interested in technological advanced companies because of higher profitability. On the other hand, foreign investors can choose firms with low technology where they can easily transfer their own technology and knowledge. Since the manufacturing of glass is a "jewel" of the Czech economy, which has a long tradition in glass manufacturing, we expect the profitability reason to be more important in their choice. Therefore, we expect a positive sign for the coefficient of this variable on the likelihood of arrival of foreign investors: we expect that foreign investors prefer Czech glassworks with higher automatic or machine-made production.

\section{Competition}

This is another control variable that captures differences in the competition and in the market-power between firms in different subsectors.

As a measure of competition or market power, we have computed the Lerner index for a firm $i$ using total costs and revenues, i.e., the cost-price margin, as in Domowitz et al. (1986):

$$
C P M_{i} \equiv \frac{\text { Sale }+\Delta \text { Inventories }- \text { Payroll }- \text { MaterialCost }}{\text { Sale }+\Delta \text { Inventories }}
$$

The ratio ranges from 0 to 1 . Firms that are in perfect competition show ratios close to zero, firms that are perfect monopolists show ratio close to 1 .

We expect a positive sign for the coefficient of this variable on the likelihood of arrival of foreign investors: we expect that foreign investors prefer Czech glassworks where they can have a higher monopoly position. 


\section{The Dependent Variable}

We use a binary variable that indicates the presence of a foreign majority owner in the Czech privatized glass firms (which has the value 1 when foreign share is $>50 \%$ of the equity).

Table 2

\section{Descriptive Statistics}

\begin{tabular}{|l|r|r|r|r|r|r|}
\hline & \multicolumn{1}{|c|}{ N } & Mean & Median & Std. dev. & \multicolumn{1}{c|}{ Min. } & Max. \\
\hline Majority foreign share (dummy) & 439 & 0.22 & 0 & 0.42 & 0 & 1 \\
\hline Productivity in 1990 (Ml. CZK) & 319 & 0.447 & 0.368 & 0.1803 & 0.1057 & 0.9265 \\
\hline Productivity in 1991 (Ml. CZK) & 207 & 0.552 & 0.437 & 0.306 & 0.04 & 1.2857 \\
\hline Productivity in 1993 (Ml. CZK) & 175 & 0.587 & 0.379 & 0.353 & 0.221 & 1.3120 \\
\hline Productivity in 1994 (Ml. CZK) & 287 & 0.630 & 0.402 & 0.503 & 0.181 & 2.283 \\
\hline Gross Profit Margin in 1993 & 199 & 0.07 & 0.09 & 0.08 & -0.08 & 0.24 \\
\hline Gross Profit Margin in 1994 & 341 & 0.08 & 0.08 & 0.07 & -0.09 & 0.26 \\
\hline Debt ratio in 1993 & 193 & 0.42 & 0.37 & 0.15 & 0.25 & 0.69 \\
\hline Debt ratio in 1994 & 335 & 0.51 & 0.45 & 0.26 & 0.12 & 1.04 \\
\hline Current ratio in 1993 & 161 & 2.81 & 2.52 & 1.85 & 1.19 & 9.11 \\
\hline Current ratio in 1994 & 423 & 2.49 & 2.11 & 1.67 & 0.26 & 7.63 \\
\hline Years since privatization & 288 & 0.69 & 7 & 4.59 & -8 & 16 \\
\hline Market power (Lerner index ) & 438 & 48.01 & 50 & 44.74 & 0 & 100 \\
\hline Machine-made production (percent) & 325 & 6.94 & 6.78 & 0.96 & 4.86 & 8.79 \\
\hline $\begin{array}{l}\text { Natural logarithm of the number of } \\
\text { employees in 1990 }\end{array}$ & 221 & 6.91 & 6.70 & 0.96 & 5.77 & 8.78 \\
\hline $\begin{array}{l}\text { Natural logarithm of the number of } \\
\text { employees in 1991 }\end{array}$ & 175 & 6.73 & 6.94 & 1.29 & 4.21 & 8.68 \\
\hline $\begin{array}{l}\text { Natural logarithm of the number of } \\
\text { employees in 1993 }\end{array}$ & 294 & 6.32 & 6.31 & 1.24 & 3.80 & 8.51 \\
\hline $\begin{array}{l}\text { Natural logarithm of the number of } \\
\text { employees in 1994 }\end{array}$ & & & & & & \\
\hline
\end{tabular}

Source: author's calculation based on companies annual reports.

Table 2 shows that productivity increased in the privatized glass sector from 1990 to 1994: the increase in productivity can be due to a reduction of the excess workforce as well as more efficient use of firm's resources thanks to the restructuring activities. The average firm in our sample had 1,617 employees in 1990 and 1,065 in 1994. The smaller firms in 1990 had 130 employees and the larger ones 6,576 employees, while in 1994, the smaller firms had 45 employees and the larger ones 4,971 employees.

\section{The Estimation Model}

Since we use a binary dependent variable, the assumptions of OLS are violated. Therefore, we decided to use the logistic regression for the analysis of the determinants 
of foreign ownership. Logistic regression involves predicting the probability of the outcome variable, given known values of the explanatory variables. The logistic regression takes the following form:

$$
P(y=1 / x)=\frac{\exp \left(\beta^{\prime} x\right)}{1+\exp \left(\beta^{\prime} x\right)}
$$

We use a logit model instead of a probit model because even if the logistic and the normal distribution on which these two models are based on are very similar to each other, except at the tails, we are not likely to get very different results unless the samples are large (so that we have enough observations at the tails) and the logistic distribution function has a much simpler form than the normal distribution form (Amemiya, 1985; Greene, 2008).

We estimate a random effects logit model. For our sample, the random effect estimator is more efficient than the fixed effect estimator because it uses both the cross-sectional and time-series component of the data being a weighted average of the within (fixed effect) and the between estimator (Kennedy, 2003). In cases where the key independent variables do not vary much over time, fixed effect and first-differencing methods can lead to imprecise estimates. If the unobserved effect is orthogonal to the independent variables, then the random effect estimator can have a much smaller variance than the fixed effect and first-difference estimator (Wooldridge, 2002). Other arguments for using random effects models instead of fixed effects models are well explained in Maddala (1993).

Because of some time-invariant crucial independent variables in our model, a fixed model is not feasible and therefore we cannot run the Hausman test. However, we can justify theoretically the use of a random estimator.

If the results are satisfactory (coefficients are statistically significant, the sign of coefficients does not vary if the number of observations changes) and there are no problems with autocorrelation and heteroscedasticity, there should not be a bias problem because of the small number of observations and the estimates should be robust (Baltagi, 2008).

Since our population is small, we check the robustness of our statistical results by running several models where we have some common variables and where we add some other variables. This procedure allows for checking the stability of our coefficients. A test for autocorrelation had not shown the presence of such problem. Therefore, if adding a new variable or variables and changing the number of observations the results do not vary, this supports the robustness of our results.

Even if a logistic regression can overcome many of the restrictive assumptions of OLS regression (such as normality and homoscedasticity), it is important that multicollinearity must be checked. Although multicollinearity does not bias the coefficients, it does make them more unstable and it is hard to get good estimates of their distinct effects on some dependent variables. Moreover, with multicollinearity standard errors may get large, and variables that appear to have no significant effects individually may actually have quite strong significant effects as a group (Wooldridge, 2003). We checked for multicollinearity effects using a Pearson correlation matrix. 


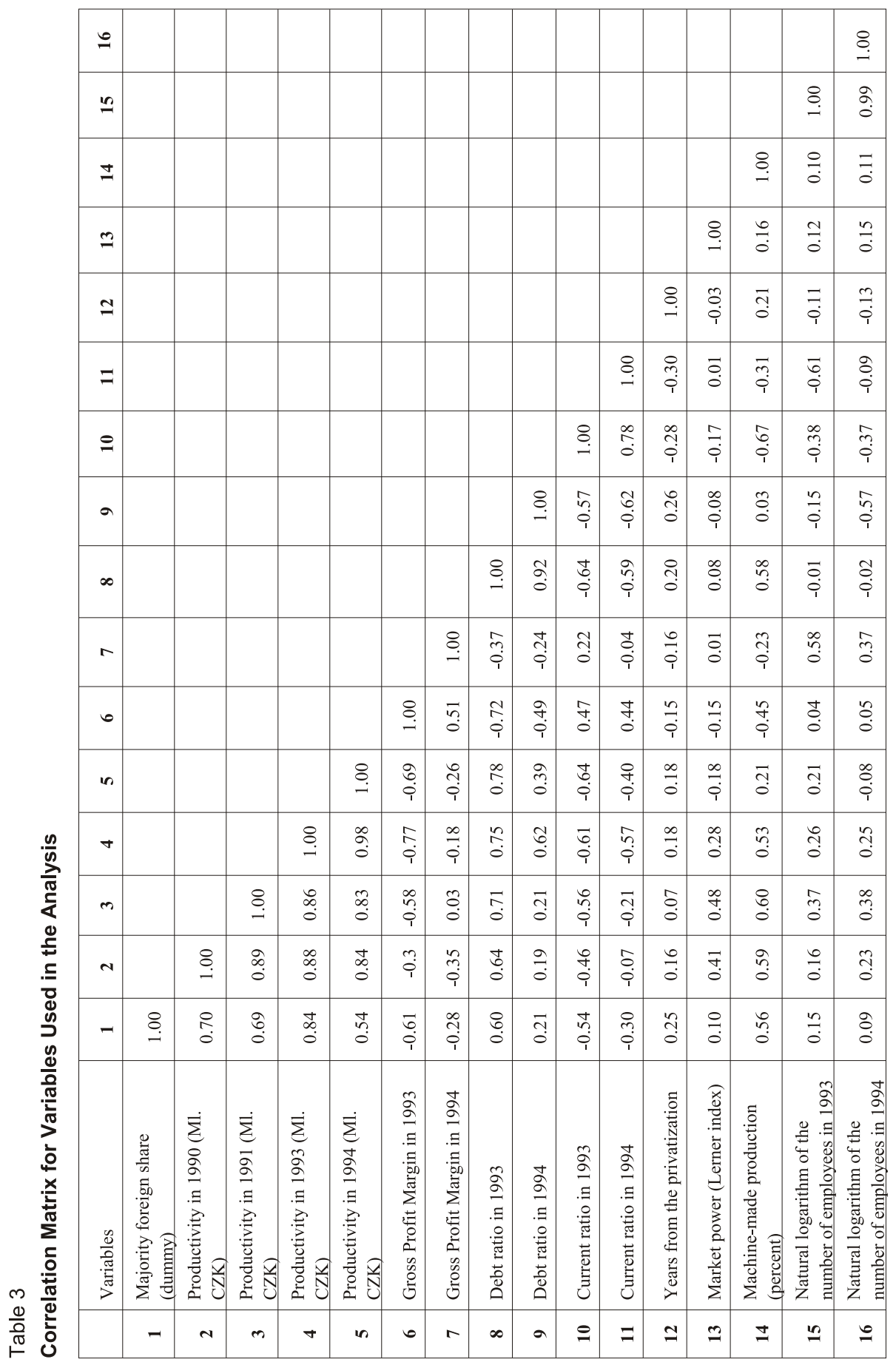

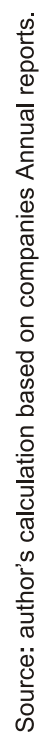


The variables that measure the firms' performance and financial state are highly correlated (Table 3). Because of multicollinearity, it is not possible to include several of them in a regression. Therefore, these variables will be used individually, together with control variables, in order to test the importance of initial performance and firm's size.

The estimated coefficients of a logit regression show which variables have a significant effect on the arrival of foreign investors and their significance give the direction of the effect of a change in the explanatory variable on the probability of arrival of foreign direct investors. Moreover, we can use the estimated coefficients to quantify the marginal effect of the explanatory variables on the probability of arrival of foreign investors.

We use a Likelihood-ratio test to compare the efficiency of the panel estimator with respect to the pooled OLS estimator. The null hypothesis is that there is no difference between the two estimators. If the null hypothesis is significantly rejected, the panel data estimator is more efficient.

As measures of fit of the models, we use the pseudo R-square and Akaike's information criterion (AIC). The pseudo R-square is based on the maximized log-likelihood function (LL) with respect to the log-likelihood for the constant only model (L0) and it is computed as follows:

$$
\text { PseudoR }{ }^{2}=\frac{2 L L-2 L 0}{2 L L}
$$

The pseudo R-square can only be used to compare nested models, but it gives a coefficient that can be interpreted as an R-square. The AIC and the Bayesian information criterion (BIC) are two other popular measures for comparing maximum likelihood models. One advantage to using information criterion measures is that they can be used to compare non-nested models. The BIC, however, depends on the number of observations and cannot be used to compare models if the sample does not have the same number of observations. Therefore, we use only the AIC measure, it is calculated as follows:

$$
A I C=-2 \ln L L+2 k \text { (where } k \text { indicates the degrees of freedom of the model) }
$$

Contrary to other authors, we have not included macro variables in the model, because the focus on an industrial sector in the Czech Republic reduces the variance among firms and the importance of factors such as the exchange rate, taxes, institutions and trade (for a review of the macro effects of these factors on FDIs see Blonigen, 2005).

\section{Empirical Results}

We explored the impact of a firm's initial characteristics on their probability of having majority foreign ownership in the glass enterprises that were privatized after 1989.

We have estimated ten different models of logit regression because with multicollinearity it is not possible to include several variables in the same regression. We will comment on our results at the $5 \%$ significance level. 
Table 4

Results of Random Effect Logistic Regressions

Dependent Variable: Presence of a Foreign Majority Owner in the Czech Privatized Glass Sector

\begin{tabular}{|c|c|c|c|c|c|c|c|c|}
\hline & \multicolumn{2}{|c|}{ Model 1} & \multicolumn{2}{|c|}{ Model 2} & \multicolumn{2}{|c|}{ Model 3} & \multicolumn{2}{|l|}{ Model 4} \\
\hline & $\begin{array}{l}\text { Coeff. } \\
\text { (Standard } \\
\text { errors) }\end{array}$ & $\begin{array}{l}\text { Mar- } \\
\text { ginal } \\
\text { effect }\end{array}$ & $\begin{array}{l}\text { Coeff. } \\
\text { (Standard } \\
\text { errors) }\end{array}$ & $\begin{array}{l}\text { Mar- } \\
\text { ginal } \\
\text { effect }\end{array}$ & $\begin{array}{l}\text { Coeff. } \\
\text { (Standard } \\
\text { errors) }\end{array}$ & $\begin{array}{l}\text { Mar- } \\
\text { ginal } \\
\text { effect }\end{array}$ & $\begin{array}{c}\text { Coeff. } \\
\text { (Standard errors) }\end{array}$ & $\begin{array}{l}\text { Mar- } \\
\text { ginal } \\
\text { effect }\end{array}$ \\
\hline $\begin{array}{l}\text { Productivity in } 1990 \\
\text { (Ml. CZK) }\end{array}$ & $\begin{array}{l}38.124 * * * \\
(10.336)\end{array}$ & 0.597 & & & & & & \\
\hline $\begin{array}{l}\text { Productivity in } 1991 \\
\text { (Ml. CZK) }\end{array}$ & & & $\begin{array}{l}20.091 * * * \\
(4.395)\end{array}$ & 3.260 & & & & \\
\hline $\begin{array}{l}\text { Productivity in } 1993 \\
\text { (Ml. CZK) }\end{array}$ & & & & & $\begin{array}{l}33.885 * * * \\
(11.840)\end{array}$ & 6.430 & & \\
\hline $\begin{array}{l}\text { Productivity in } 1994 \\
\text { (Ml. CZK) }\end{array}$ & & & & & & & $\begin{array}{l}13.513 * * * \\
(3.467)\end{array}$ & 0.046 \\
\hline $\begin{array}{l}\text { Logarithm of the num. } \\
\text { of employees in } 1993\end{array}$ & & & & & $\begin{array}{l}2.734^{* *} \\
(1.21)\end{array}$ & 0.519 & & \\
\hline $\begin{array}{l}\text { Logarithm of the num. } \\
\text { of employees in } 1994\end{array}$ & & & & & & & $\begin{array}{l}2.541 * * * \\
(0.792)\end{array}$ & 0.086 \\
\hline $\begin{array}{l}\text { Years from the } \\
\text { privatization }\end{array}$ & $\begin{array}{l}0.646 * * * \\
(0.169)\end{array}$ & 0.010 & $\begin{array}{l}0.623 * * * \\
(0.156)\end{array}$ & 0.101 & $\begin{array}{l}0.830 * * * \\
(0.301)\end{array}$ & 0.157 & $\begin{array}{l}0.698 * * * \\
(0.207)\end{array}$ & 0.004 \\
\hline $\begin{array}{l}\text { Market power } \\
\text { (Lerner index) }\end{array}$ & $\begin{array}{r}4.403 \\
(4.523)\end{array}$ & 0.069 & $\begin{array}{c}2.902 \\
(4.704)\end{array}$ & 0.471 & $\begin{array}{l}28.502 * * \\
(11.261)\end{array}$ & 5.409 & $\begin{array}{l}3.516 \\
(5.149)\end{array}$ & 0.012 \\
\hline $\begin{array}{l}\text { Machine-made } \\
\text { production (percent) }\end{array}$ & $\begin{array}{r}0.041 \\
(0.035)\end{array}$ & 0.001 & $\begin{array}{l}0.079^{*} \\
(0.043)\end{array}$ & 0.013 & & & $\begin{array}{l}0.193 * * * \\
(0.052)\end{array}$ & 0.001 \\
\hline Constant & $\begin{array}{l}-29.007^{* * *} \\
(6.826)\end{array}$ & & $\begin{array}{l}-24.058 * * * \\
(5.367)\end{array}$ & & $\begin{array}{l}-51.625^{* * *} \\
(18.760)\end{array}$ & & $\begin{array}{l}-49.764 * * * \\
(11.669)\end{array}$ & \\
\hline Wald Chi-Square & \multicolumn{2}{|c|}{$20.44 * * *$} & \multicolumn{2}{|c|}{$31.97 * * *$} & \multicolumn{2}{|c|}{$10.35^{* *}$} & \multicolumn{2}{|c|}{$20.42 * * *$} \\
\hline Sample size & \multicolumn{2}{|c|}{226} & \multicolumn{2}{|c|}{158} & \multicolumn{2}{|c|}{141} & \multicolumn{2}{|l|}{204} \\
\hline LR test ${ }^{\mathrm{a}}$ & \multicolumn{2}{|c|}{$46.81^{* * *}$} & \multicolumn{2}{|c|}{$28.29^{* * * *}$} & \multicolumn{2}{|c|}{$22.43 * * *$} & \multicolumn{2}{|c|}{$44.61 * * *$} \\
\hline Pseudo R-squared & \multicolumn{2}{|c|}{0.685} & \multicolumn{2}{|c|}{0.733} & \multicolumn{2}{|l|}{0.891} & \multicolumn{2}{|l|}{0.727} \\
\hline AIC & \multicolumn{2}{|c|}{66.028} & \multicolumn{2}{|c|}{57.895} & \multicolumn{2}{|l|}{30.718} & \multicolumn{2}{|l|}{60.824} \\
\hline
\end{tabular}

Source: author's calculation based on companies annual reports

Note: * significant at 10\%; ** significant at 5\%; ${ }^{* *}$ significant at 1\%; a LR test denotes the likelihood-ratio test, which provides a test for pooled (logit) estimator against the random effects panel estimator.

The regressions using initial conditions in 1990 and 1991 (Table 4) suggest that foreign investors had chosen glass firms with higher initial productivity. The marginal effect of productivity in 1990 (measured in Ml. CZK) is 0.597: this means that an increase of one million Czech korunas in the productivity in 1990 was associated with a $59.7 \%$ increase in the probability of arrival of foreign investors. The marginal effect of productivity is even stronger in 1991, i.e. it is 3.260 which means that an increase of one million Czech korunas in the productivity was associated with a $326 \%$ increase in the probability of arrival of foreign investors. The value of productivity in 1993 and 1994 also positively affects the likelihood of having a foreign investor in a Czech glass firm. 
Firm size also positively affects the likelihood of having a foreign investor in a Czech glass firm: foreign investors have chosen larger firms in terms of the number of employees.

The number of years from the privatization is positively associated with the likelihood of arrival of foreign investors. Foreign investors have preferred firms that were privatized early. Our measure of market power, the Lerner index, and the percentage of automatic production have a positive relationship with the arrival of foreign investors but the coefficients are not significant in all models.

Table 5

Results of Random Effect Logistic Regressions

Dependent Variable: Presence of a Foreign Majority Owner in the Czech Privatized Glass Sector

\begin{tabular}{|c|c|c|c|c|}
\hline & \multicolumn{2}{|c|}{ Model 5} & \multicolumn{2}{|c|}{ Model 6} \\
\hline & $\begin{array}{c}\text { Coeff. } \\
\text { (Standard errors) }\end{array}$ & Marginal effect & $\begin{array}{c}\text { Coeff. } \\
\text { (Standard errors) }\end{array}$ & Marginal effect \\
\hline $\begin{array}{l}\text { Gross Profit Margin } \\
\text { in } 1993\end{array}$ & $\begin{array}{l}-87.866^{* * * *} \\
(25.193)\end{array}$ & -0.832 & & \\
\hline $\begin{array}{l}\text { Gross Profit Margin } \\
\text { in } 1994\end{array}$ & & & $\begin{array}{l}-25.565^{* *} \\
(13.673)\end{array}$ & -0.526 \\
\hline $\begin{array}{l}\text { Logarithm of the } \\
\text { number of employees } \\
\text { in } 1994\end{array}$ & & & $\begin{array}{l}1.981^{* *} \\
(0.982)\end{array}$ & 0.041 \\
\hline $\begin{array}{l}\text { Years from the } \\
\text { privatization }\end{array}$ & $\begin{array}{l}0.451 * * * \\
(0.143)\end{array}$ & 0.004 & $\begin{array}{l}0.454 * * * \\
(0.126) \\
\end{array}$ & 0.009 \\
\hline $\begin{array}{l}\text { Market power } \\
\text { (Lerner index ) }\end{array}$ & $\begin{array}{l}10.418^{*} \\
(6.275)\end{array}$ & 0.098 & $\begin{array}{c}8.500 * \\
(4.494)\end{array}$ & 0.175 \\
\hline $\begin{array}{l}\text { Machine-made } \\
\text { production (percent) }\end{array}$ & $\begin{array}{l}0.079 * * \\
(0.039)\end{array}$ & 0.001 & $\begin{array}{l}0.093 * * \\
(0.043)\end{array}$ & 0.002 \\
\hline Constant & $\begin{array}{l}-8.167 * * \\
(3.149)\end{array}$ & & $\begin{array}{l}-25.504 * * * \\
(8.661)\end{array}$ & \\
\hline Wald Chi-Square & \multicolumn{2}{|c|}{$19.15 * * *$} & \multicolumn{2}{|c|}{$22.80 * * *$} \\
\hline Sample size & \multicolumn{2}{|c|}{161} & \multicolumn{2}{|c|}{204} \\
\hline LR test $\mathrm{t}^{\mathrm{a}}$ & \multicolumn{2}{|c|}{$20.13 * * *$} & \multicolumn{2}{|c|}{$76.13 * * *$} \\
\hline Pseudo R-squared & \multicolumn{2}{|c|}{0.777} & \multicolumn{2}{|c|}{0.614} \\
\hline AIC & \multicolumn{2}{|c|}{50.203} & \multicolumn{2}{|c|}{80.251} \\
\hline
\end{tabular}

Source: author's calculation based on companies annual reports.

Note: * significant at $10 \%$; ${ }^{* *}$ significant at $5 \%$; ${ }^{* * *}$ significant at $1 \%$; a LR test denotes the likelihood-ratio test, which provides a test for pooled (logit) estimator against the random effects panel estimator.

Table 5 shows that the amount of gross profit margin in 1993 and 1994 is negatively associated with the arrival of a foreign investor. Foreign investors have invested in glass firms with higher productivity and with negative profit margins at the beginning of the transition. This relationship can be explained by the fact that foreign investors have chosen firms with high potentialities, expressed by high total sales per employee, and that were restructuring hardly in these years, having therefore greater costs of 
restructuring and negative profit margins. The number of years from the privatization is positively associated with the likelihood of arrival of foreign investors and the coefficient is significant. The Lerner index has a positive relationship with the arrival of foreign investors but the coefficient is not significant at $5 \%$ level. The percentage of automatic production has a positive relationship with the arrival of foreign investors and the coefficient is significant.

Table 6

Results of Random Effect Logistic Regressions

Dependent variable: Presence of a Foreign Majority Owner in the Czech Privatized Glass Sector

\begin{tabular}{|c|c|c|c|c|c|c|c|c|}
\hline & \multicolumn{2}{|c|}{ Model 7} & \multicolumn{2}{|c|}{ Model 8} & \multicolumn{2}{|c|}{ Model 9} & \multicolumn{2}{|c|}{ Model 10} \\
\hline & $\begin{array}{l}\text { Coeff. } \\
\text { (Standard } \\
\text { errors) }\end{array}$ & $\begin{array}{r}\text { Mar- } \\
\text { ginal } \\
\text { effect }\end{array}$ & $\begin{array}{l}\text { Coeff. } \\
\text { (Standard } \\
\text { errors) }\end{array}$ & $\begin{array}{r}\text { Mar- } \\
\text { ginal } \\
\text { effect }\end{array}$ & $\begin{array}{l}\text { Coeff. } \\
\text { (Standard } \\
\text { errors) }\end{array}$ & $\begin{array}{l}\text { Mar- } \\
\text { ginal } \\
\text { effect }\end{array}$ & $\begin{array}{l}\text { Coeff. } \\
\text { (Standard } \\
\text { errors) }\end{array}$ & $\begin{array}{l}\text { Mar- } \\
\text { ginal } \\
\text { effect }\end{array}$ \\
\hline Debt ratio in 1993 & $\begin{array}{l}24.798 * * * \\
(9.334)\end{array}$ & 1.701 & & & & & & \\
\hline Debt ratio in 1994 & & & $\begin{array}{l}12.742 * * * \\
(3.988) \\
\end{array}$ & 0.381 & & & & \\
\hline Current ratio in 1993 & & & & & $\begin{array}{l}-5.005 * * \\
(1.952)\end{array}$ & -0.059 & & \\
\hline Current ratio in 1994 & & & & & & & $\begin{array}{l}-2.474 * * * \\
(0.729)\end{array}$ & -0.029 \\
\hline $\begin{array}{l}\text { Logarithm of the num. } \\
\text { of employees in } 1993\end{array}$ & $\begin{array}{l}2.688^{* *} \\
(1.225)\end{array}$ & 0.184 & & & $\begin{array}{l}1.836^{*} \\
(1.115)\end{array}$ & 0.022 & & \\
\hline $\begin{array}{l}\text { Logarithm of the num. } \\
\text { of employees in } 1994\end{array}$ & & & $\begin{array}{l}2.441 * * * \\
(0.785)\end{array}$ & 0.072 & & & $\begin{array}{l}1.698^{* *} \\
(0.774)\end{array}$ & 0.020 \\
\hline $\begin{array}{l}\text { Years from the } \\
\text { privatization }\end{array}$ & $\begin{array}{l}0.548^{* * *} \\
(0.177)\end{array}$ & 0.038 & $\begin{array}{l}0.458^{* * * *} \\
(0.124)\end{array}$ & 0.014 & $\begin{array}{l}0.674 * * * \\
(0.225)\end{array}$ & 0.008 & $\begin{array}{l}0.441^{* * *} \\
(0.125)\end{array}$ & 0.005 \\
\hline $\begin{array}{l}\text { Market power } \\
\text { (Lerner index) }\end{array}$ & $\begin{array}{r}6.096 \\
(6.652) \\
\end{array}$ & 0.418 & $\begin{array}{r}3.603 \\
(4.154) \\
\end{array}$ & 0.108 & $\begin{array}{c}7.941 \\
(8.058) \\
\end{array}$ & 0.093 & $\begin{array}{r}6.716 \\
(4.641) \\
\end{array}$ & 0.080 \\
\hline $\begin{array}{l}\text { Machine-made } \\
\text { production (percent) }\end{array}$ & $\begin{array}{c}0.131^{*} \\
(0.070)\end{array}$ & 0.009 & $\begin{array}{l}0.107 * * * \\
(0.034)\end{array}$ & 0.003 & $\begin{array}{l}0.125^{*} \\
(0.068)\end{array}$ & 0.001 & $\begin{array}{l}0.122^{* * *} \\
(0.043)\end{array}$ & 0.001 \\
\hline Constant & $\begin{array}{l}-46.731 * * * \\
(16.937)\end{array}$ & & $\begin{array}{l}-36.873 * * * \\
(8.396)\end{array}$ & & $\begin{array}{l}-19.313^{*} \\
(11.014)\end{array}$ & & $\begin{array}{l}-22.093 * * * \\
(7.565)\end{array}$ & \\
\hline Wald Chi-Square & \multicolumn{2}{|c|}{$14.07^{* *}$} & \multicolumn{2}{|c|}{$30.26^{* * *}$} & \multicolumn{2}{|c|}{$14.79^{* *}$} & \multicolumn{2}{|c|}{$33.84 * * *$} \\
\hline Sample size & \multicolumn{2}{|c|}{138} & \multicolumn{2}{|l|}{203} & \multicolumn{2}{|c|}{129} & \multicolumn{2}{|c|}{199} \\
\hline LR test ${ }^{\mathrm{a}}$ & \multicolumn{2}{|c|}{$40.21^{* * *}$} & \multicolumn{2}{|c|}{$56.08^{* * *}$} & \multicolumn{2}{|c|}{$21.31 * * *$} & \multicolumn{2}{|c|}{$57.15^{* * *}$} \\
\hline Pseudo R-squared & \multicolumn{2}{|c|}{0.768} & \multicolumn{2}{|l|}{0.599} & \multicolumn{2}{|c|}{0.814} & \multicolumn{2}{|c|}{0.639} \\
\hline AIC & \multicolumn{2}{|l|}{53.867} & \multicolumn{2}{|l|}{82.905} & \multicolumn{2}{|c|}{45.997} & \multicolumn{2}{|c|}{75.901} \\
\hline
\end{tabular}

Source: author's calculation based on companies annual reports.

Note: * significant at 10\%; ${ }^{* *}$ significant at 5\%; ${ }^{* *}$ significant at $1 \%$; ${ }^{\text {a }}$ LR test denotes the likelihood-ratio test, which provides a test for pooled (logit) estimator against the random effects panel estimator.

If we take into account the financial state of the companies in 1993 and 1994 (Table 6), foreign investors have chosen firms that at the beginning of the transition had a 
higher debt ratio and lower current ratio. This result is in contrast with some previous empirical studies that found a positive relationship between the initial financial state and the probability of arrival of foreign investors, even if this evidence is weak. Since foreign investors have invested in firms which had a lower gross profit margin in 1993 and 1994, we suspect that the same reason explains the arrival of foreign investors in firms with high debt ratios in these years. Firms that were restructuring hard at the beginning of the transition had higher debts compared to their assets, also in the short term (as the current ratio shows), suggesting that these firms had quickly solved the soft budget constraint problem. The refinancing of many loss-making enterprises was common during central planning and having financial problems in the transition was a signal of restructuring activity and of hardening of the budget constraints.

The number of years from privatization is again strongly related to the probability of receiving a foreign investor: foreign investors entered more in firms privatized early.

Having a higher share of machine-made production is positively associated with the likelihood of arrival of a foreign investor: firms with automatic production have a higher likelihood of being chosen by a foreign investor; however, this coefficient is not significant at the $5 \%$ level in all models.

There is a positive relationship between the firm's market power, expressed by the Lerner index, and the likelihood of arrival of a foreign investor but this coefficient is not significant. The significant coefficients in the regressions suggest that foreign investors in the glass sector have chosen larger firms, potentially more profitable, that were minimally restructuring and that were privatized early. A firm's initial characteristics did matter in the glass sector and have affected the likelihood of arrival of a foreign investor in the Czech Republic.

The marginal effects of the independent variables in different model cannot be compared because of the unequal sample size and different variables included in the regressions. However, the marginal effects of the initial productivity, firm size and financial conditions are larger than the marginal effects of the control variables. This further supports the relevance of firm's characteristics on the likelihood of arrival of foreign investors.

\section{Conclusions}

This paper analyses the determinants of foreign direct investments in the privatized glass sector in the Czech Republic. We have investigated whether the choice of a foreign investor is motivated by firm's characteristics and which of these firm's characteristics are relevant using a data set from 42 privatized firms in the glass sector. We present different regression models that show the relevance of firm's characteristics in the choice of foreign investors. Multicollinearity does not allow to find one econometric model that includes all firm-level determinants of FDI. The likelihood-ratio test shows that the random-effect model is more efficient than the pooled OLS in all models.

The results of our econometrical analysis give strong evidence that foreign direct investors in the glass sector in the Czech Republic have chosen larger and more profitable firms, and this preference is not affected by the time of arrival of foreign investors. Quicker foreign direct investors have chosen more productive firms and foreign investors that arrived later have continued to prefer more productive firms. 
Moreover, foreign investors have given preference to firms that were intensively restructured at the beginning of the transition, shown by higher debt ratios, lower current ratio and negative profit margins, and that were privatized early.

Following the above discussion, our results support our Hypotheses 1 and 2.

The evidence of this paper supports the view of the relevance of the endogeneity issue in the choice of foreign direct investors in transition countries and the theory of Demsetz (1983) and Demsetz and Lehn (1985), which states that the ownership structure is not exogenous, but it is the result of the characteristics of firms.

The choice of an industrial sector hinders the generalization of these results to other sectors in the Czech Republic. However, the results of our study align with the findings of previous empirical studies implemented in different industrial sectors and countries. Therefore, even if it is not possible to generalize our results to other sectors or transition countries, our study points to the relevance of the endogeneity issue, to the importance of the firm's characteristics in the choice of foreign investors in transition countries and the need of further research about this topic in other industrial sectors in transition countries.

\section{References}

Amemiya, T. (1985), Advanced Econometrics. $1^{\text {st }}$ Edition. Cambridge, Massachusetts: Harvard University Press.

Anderson, W. C., Jandik, T., Makhija, K. A. (2001), "Determinants of Foreign Ownership in Newly Privatized Companies in Transition Economies", Financial Review, 36 (2), pp. 161-176.

Arnold, J. M., Javorcik, B. S. (2005), "Gifted Kids or Pushy Parents? Foreign Acquisitions and Plant Performance in Indonesia", Washington D.C.: World Bank Policy Research Working Paper No. 3597.

Association of the Glass and Ceramic Industry of the Czech Republic (2001), Annual Report 2001.

Association of the Glass and Ceramic Industry of the Czech Republic (2007), Annual Report 2007.

Baltagi, B. H. (2008), Econometric analysis of panel data. $4^{\text {th }}$ Edition. Chichester, GB: John Wiley \& Sons.

Barrell, R., Holland. D. (2000), "Foreign Direct Investment and Enterprise Restructuring in Central Europe", Economics of Transition, 8 (2), pp. 477-504.

Benáček, V. (2000), "Foreign Direct Investment in the Czech Economy”, Politická ekonomie, 48 (1), pp. 7-24.

Benáček, V., Zemplinerová, A. (1997), "Foreign Direct Investment in the Czech Manufacturing Sector", Prague Economic Papers, 6 (2), pp. 141-155.

Bishop, K., Filatotchev, I., Mickiewicz, T. M. (2002), "Endogenous Ownership Structure”, Acta Oeconomica, 52 (4), pp. 443-471.

Blonigen, B. A. (2005), "A Review of the Empirical Literature on FDI determinants", Atlantic Economic Journal, 33, pp. 383-403.

Boardman, A., Vining, A. R. (1989), "Ownership and Performance in Competitive Environments: A Comparison of the Performance of Private, Mixed, and State-Owned Enterprises", Journal of Law and Economics, 32 (1), pp. 1-33.

Boycko M., Shleifer, A., Vishny, R. (1995). Privatising Russia. $1^{\text {st }}$ Edition. Cambridge, MA: MIT Press.

Cho, M.-H. (1998), "Ownership Structure, Investment, and the Corporate Value: An Empirical Analysis", Journal of Financial Economics, 47, pp. 103-121.

Claessens, S., Djankov, S. (1999), "Ownership Concentration and Corporate Performance in the Czech Republic", Journal of Comparative Economics, 27, pp. 498-513.

Crystalex Branch Corporation (1985), Bohemian Glass, the History of Bohemian Glass and the Present at the Crystalex, Nový Bor: Ed. Vincenc Kutač.

Dahlquist, M., Robertsson, G. (2001), "Direct Foreign Ownership, Institutional Investors, and Firm Characteristics", Journal of Financial Economics, 59 (3), pp. 413-440. 
De Arriba Bueno, R. (2007), "Is Privatization Enough to Create a Market Economy? The Bulgarian Experience", Transformations in Business \& Economics, 6 (1), pp. 71-84.

Demsetz, H. (1983), "The Structure of Ownership and the Theory of the Firm", Journal of Law and Economics, 26, pp. 375-390.

Demsetz, H., Lehn, K. (1985), "The Structure of Corporate Ownership: Causes and Consequences", Journal of Political Economy, 93 (6), pp. 1155-1177.

Demsetz, H., Villalonga, B. (2001), "Ownership Structure and Corporate Performance", Journal of Corporate Finance, 7, pp. 209-233.

Djankov, S., Hoekman, B. (2000), "Foreign Investments and Productivity Growth in Czech Enterprises", The World Bank Economic Review, 14 (1), pp. 49-64.

Djankov, S., Murrell, P. (2000), The Determinants of Enterprise Restructuring in Transition: An Assessment of the Evidence. Washington, D.C.: The World Bank Paper, No. 20942.

Djankov, S., Murrell, P. (2002), "Enterprise Restructuring in Transition: A Quantitative Survey", Journal of Economic Literature, 40 (3), pp. 739-792.

Domowitz, I., Hubbard, R. G., Petersen, B. C. (1986), "Business Cycles and the Relationship between Concentration and Price-Cost Margins", The RAND Journal of Economics, 17 (1), pp. 1-17.

Dunning, J. H. (1980), "Toward an Eclectic Theory of International Production: Some Empirical Tests", Journal of International Business Studies, 11 (1), pp. 9-31.

Dunning, J. H. (1981), International Production and the Multinational Enterprise. $1^{\text {st }}$ Edition. London: George Allen and Unwin.

Dunning, J. H. (1998), "Location and the Multinational Enterprise: A Neglected Factor?", Journal of International Business Studies, 29 (1), pp. 45-66.

Dunning, J. H. (2000), "The Eclectic Paradigm as an Envelope for Economic and Business Theories of MNE Activity", Journal of International Business Studies, 9, pp. 163-190.

Dyck, I. J. A. (1997), "Privatization in Eastern Germany: Management Selection and Economic Transition", The American Economic Review, 87 (4), pp. 565-597.

Frydman R., Gray, C., Hessel, M., Rapaczynski, A. (1999), "When Does Privatization Works? The Impact of Private Ownership on Corporate Governance in the Transition Economies", The Quarterly Journal of Economics, 114 (4), pp. 1154-1191.

Greene, W. H. (2008), Econometric Analysis. $6^{\text {th }}$ Edition. New Jersey: Prentice Hall.

Gupta, N., Ham, J., Svejnar, J. (2000), "Priorities and Sequencing in Privatization: Theory and Evidence from the Czech Republic". Michigan: University of Michigan Business School, William Davidson Institute, (revised 2001), Working Paper No. 323. Available on line at http://ssrn.com/ abstract $=294541$

Hanousek, J., Kočenda, E., Svejnar, J. (2004), "Spinoffs, Privatization and Corporate Performance in Emerging Markets". Michigan: University of Michigan Business School, William Davidson Institute, Working Paper No. 685.

Hanousek, J., Kočenda, E., Svejnar, J. (2007), "Origin and Concentration: Corporate Ownership, Control and Performance in Firms after Privatization", Economics of Transition, 15 (1), pp. 1-31.

Hashi, I. (1998), "Mass Privatization and Corporate Governance in Czech Governance", Economic Analysis, 1 (2), pp. 163-187.

Himmelberg, P. C., Hubbard, R. G., Palia, D. (1999), "Understanding the Determinants of Managerial Ownership and the Link between Ownership and Performance", Journal of Financial Economics, 53 (3), pp. 353-384.

Kadeřábková, A. (2007), "Technology Intensity and FDI in the Czech Republic Competitive Advantage", Politická ekonomie, 55 (3), pp. 354-373.

Kang, J., Stulz, R. (1997), "Why Is There a Home Bias? An Analysis of Foreign Portfolio Equity in Japan?" Journal of Financial Economics, 29, pp. 3-28.

Kennedy, P. (2003), A Guide to Econometrics. $5^{\text {th }}$ Edition. Cornwall: Blackwell Publishing.

Kočenda, E. (2003), "Performance of Czech Voucher-Privatized Firms", Prague Economic Papers, 2 (2), pp. 121-130.

Kole, S. (1996), "Managerial Ownership and Firm Performance: Incentives or Rewards?", Advances in Financial Economics, 2, pp. 119-149.

Konings, J. (2001), "The Effects of Direct Foreign Investment on Domestic Firms: Evidence from Firm Level Panel Data in Emerging Economies", Economics of Transition, 9 (3), pp. 619-633. 
Lízal, L., Švejnar, J. (2002), "Privatization Revisited: the Effects of Foreign and Domestic Owners on Corporate Performance". Prague: CERGE-El, Discussion Paper No. 89.

Loderer, C., Martin, K. (1997), "Executive Stock Ownership and Performance Tracking Faint Traces", Journal of Financial Economics, 45 (2), pp. 223-255.

Maddala, G. S. (1993), The Econometrics of Panel Data. $1^{\text {st }}$ Edition. Aldershot: Edward Elgar.

Marcincin, A., van Wijnbergen, S. (1997), "The Impact of Czech Privatization Methods on Enterprise Performance Incorporating Initial Selection-Bias Correction”, Economics of Transition, 5 (2), pp. 289-304.

Megginson, L. W., Netter, J. M. (2001), "From State to Market: A Survey of Empirical Studies on Privatization", Journal of Economic Literature, 39, pp. 321-389.

Ministry of Industry (1991), REGISTER of Companies and Organizations within the Ministry of Industry of the Czech Republic. Czechoslovakia: IDEA - Service Trading Czechoslovakia.

Ministry of Industry (1992), REGISTER of Companies within the Ministry of Industry of the Czech Republic. Czechoslovakia: IDEA - Information and Trade Agency Czechoslovakia.

Raff, H., Ryan, M. J. (2006) "Firm-Specific Characteristics and the Timing of Foreign Direct Investment Projects". Münich: CESifo, Working Paper Series No. 1874.

Srholec, M. (2003), "Foreign Direct Investment and Technology Change”, Politická ekonomie, 51 (5), pp. 695-713.

Tóth, P., Zemčík, P. (2006), "What Makes Firms in Emerging Markets Attractive to Foreign Investors? Micro-Evidence from the Czech Republic". Prague: CERGE-EI Working Paper No. 294.

Weiss, A., Nikitin, G. (2004), "Foreign Portfolio Investment Improves Performance: Evidence from Czech Republic", Topics in Economic Analysis \& Policy, 4 (1), Article 15.

Wooldridge, J. (2002), Econometric Analysis of Cross Section and Panel Data. ${ }^{\text {st }}$ Edition. Cambridge, Massachusetts: MIT Press.

Wooldridge, J. M. (2003), Introductory Econometrics: A Modern Approach. $2^{\text {nd }}$ Edition. Mason, Ohio: South-Western - Thomson Learning.

Zamrazilová, E. (2007), "Foreign Direct Investment in the Czech Republic: Selected Macroeconomic Issues, Politická ekonomie, 55 (5), pp. 579-602 